\title{
Dental Pulp Tissue Engineering
}

\author{
Flávio Fernando DEMARCO ${ }^{1}$ \\ Marcus Cristian Muniz CONDE ${ }^{1}$ \\ Bruno Neves CAVALCANTI ${ }^{2}$ \\ Luciano CASAGRANDE ${ }^{3}$ \\ Vivien Thiemy SAKAI ${ }^{4}$ \\ Jacques Eduardo NÖR ${ }^{5}$
}

\author{
${ }^{1}$ Graduate Program in Dentistry, UFPel - Federal University of Pelotas, Pelotas, RS, Brazil \\ ${ }^{2}$ Department of Dentistry, UNITAU - University of Taubaté, Taubaté, SP, Brazil \\ ${ }^{3}$ Department of Pediatric Dentistry, Dental School, UFRGS - Federal University of Rio Grande do Sul, Porto Alegre, RS, Brazil \\ ${ }^{4}$ Dental School, UNIFAL - Federal University of Alfenas, Alfenas, MG, Brazil \\ ${ }_{5}^{5}$ Angiogenesis Research Laboratory, Department of Cariology, Restorative Sciences, and Endodontics, Dental School; \\ Department of Biomedical Engineering, College of Engineering; Department of Otolaryngology, School of Medicine, \\ University of Michigan, Ann Arbor, Michigan, MI, USA
}

\begin{abstract}
Dental pulp is a highly specialized mesenchymal tissue that has a limited regeneration capacity due to anatomical arrangement and postmitotic nature of odontoblastic cells. Entire pulp amputation followed by pulp space disinfection and filling with an artificial material cause loss of a significant amount of dentin leaving as life-lasting sequelae a non-vital and weakened tooth. However, regenerative endodontics is an emerging field of modern tissue engineering that has demonstrated promising results using stem cells associated with scaffolds and responsive molecules. Thereby, this article reviews the most recent endeavors to regenerate pulp tissue based on tissue engineering principles and provides insightful information to readers about the different aspects involved in tissue engineering. Here, we speculate that the search for the ideal combination of cells, scaffolds, and morphogenic factors for dental pulp tissue engineering may be extended over future years and result in significant advances in other areas of dental and craniofacial research. The findings collected in this literature review show that we are now at a stage in which engineering a complex tissue, such as the dental pulp, is no longer an unachievable goal and the next decade will certainly be an exciting time for dental and craniofacial research.
\end{abstract}

Key Words: Endodontics, angiogenesis, scaffolds, odontoblasts, stem cells.

\section{INTRODUCTION}

The dental pulp is a highly specialized mesenchymal tissue characterized by the presence of odontoblasts and by the fact that it is surrounded by a rigid mineralized tissue (1). The dental pulp is infiltrated by a network of blood vessels and nerve bundles emanating from the apical region (2). Damage to the dental pulp by mechanical, chemical, thermal, and microbial irritants activate various types of inflammatory responses involving complex vascular, lymphatic, and local tissue reactions ( 3 ).

The possibility of pulp tissue regeneration is restricted by several factors (4). Due to anatomical arrangement of pulp chamber, the dental pulp has minimal collateral blood supply, impairing the ability of the immune system to combat infections (5). Furthermore, odontoblasts are post-mitotic cells that have limited (or no) ability to proliferate (6). The tooth reparative competence is observed when superficial carious lesions stimulate odontoblastic cells to increase their secretory activity (4). If suitable conditions prevail, odontoblasts elaborate reparative (tertiary) dentin, a more poorly organized and mineralized matrix compared to primary and secondary dentin (2). The new dentin serves to protect the pulp from bacterial by-products and/or the actual bacteria.

Dentin presents a tubular structure that maintains it in an intimate relationship with the pulp tissue through the odontoblastic process (4). Nevertheless, when teeth

Correspondence: Dr. Jacques E. Nör, University of Michigan, 1011 N. University Rm. 2309, 48109-1078 Ann Arbor, MI, USA. Tel: +1-734-9369300. Fax:+1-734-936-9300. e-mail: jenor@umich.edu / flavio.demarco@pq.cnpq.br 
suffer injuries, such as trauma, deep cavity preparation or severe caries lesions (7) the odontoblasts may succumb, possibly leading the dental pulp to irreversible pulpitis or necrosis (4). Generally, conventional endodontic therapy is indicated in such situations. Despite the positive results observed following endodontic treatment, there are significant drawbacks (5). For example, the endodontic treatment causes loss of a significant amount of dentin leaving as life-lasting sequelae a non-vital and weakened tooth (8). This is especially critical when dealing with dental trauma in young patients with immature teeth, a frequent occurrence in clinical dental practice. In order to avoid such problems and aiming at maintaining the tooth vital, new treatment strategies have been developed, based on tissue engineering principles (9). Tissue engineering is an emerging interdisciplinary science, which aims at developing strategies for regeneration of damaged organs and tissues, based on principles of engineering and life sciences (1). This field of science is grounded in the interplay of three essential components: scaffolds, responsive cells, and morphogens $(1,2,10)$.

Responsive cells are generally stem cells. They are undifferentiated cells with varying degrees of potency and plasticity, capable of self-renewal and multilineage differentiation $(1,11)$. There are two basic categories of stem cells classified according to their potential of differentiation: embryonic stem cells (ESC) (11) and somatic stem cells (also called adult stem cells or mesenchymal stem cells - MSC) (12). While the use of ESC is limited by ethical issues, somatic stem cells constitute a more favorable cellular source to be used in tissue engineering (12). Postnatal stem cells have been isolated from several tissues including, brain, skin, hair follicles, skeletal muscle, bone marrow and dental tissue (13), and five types of dental MSC were isolated an characterized: dental pulp stem cells (DPSC) from pulp of permanent teeth (14); stem cells of human exfoliated teeth (SHED) and immature dental stem cells (IDPSC) from primary teeth $(15,16)$; periodontal ligament stem cells (PDLSC) (17); stem cells from apical papilla (SCAP) $(18,19)$, and dental follicle progenitor cells (DFPC) (20). It has been shown that DPSC are capable of differentiating in odontoblast-like cells $(21,22)$ or endothelial cells (23). When transplanted in tooth slice/ scaffolds, these cells generate a pulp-like tissue (24) and differentiate into functional odontoblasts and vascular endothelial cells (23). Despite of the promising results observed with somatic stem cells, the access to stem cells might constitute an impediment to tissue engineering in some circumstances. In these cases, induced pluripotent stem (iPS) cells, which are reprogrammed somatic cells with similar characteristics to ESC, might constitute a viable alternative (25), should the requirement for the use of oncogenes be eliminated.

Scaffolds may serve as a 3-D framework for cells serving as an extracellular matrix for a finite period of time. Scaffolds provide an environment that allows both cell migration and proliferation (2), and may be fabricated in pre-determined shapes and composition. Natural and synthetic polymers have been largely employed for this purpose (26). Natural polymers in general provide better biocompatibility, whilst synthetic polymers allow for improved control of physicochemical properties, such as degradation rate, microstructure, and mechanical strength (27). The physicomechanical characteristics of scaffolds (e.g.: shape and size of pores, rate of porosity, interconnectivity) are critical determinants of cell behavior and, consequently, tissue formation (24,26-28). Furthermore, scaffolds can be functionalized with bioactive molecules, such as growth factors, to guide tissue formation or network vessel development (29).

Morphogens are proteins that induce cell signaling, influencing critical functions like cell division, matrix synthesis and proliferation (1). These proteins can be active even at very low concentrations in the picogram range (30). Morphogens are classified according to their activity. While cytokines (e.g. TNFalpha, TNF-beta) are associated with inflammatory and immune reactions (30), growth factors (e.g. amelogenin, TGF, BMP) act as stimulators or inhibitors of growth $(1,30)$. In dentinogenesis, growth factors orchestrate epithelial-mesenchymal interactions that regulate the differentiation and function of cells responsible for the generation of dental tissues (31). Postnatal dental tissue regeneration recapitulates events that have occurred in embryonic development (30). After complete development, dentin retains "fossilized" growth factors that can be released when the dentin is solubilized (32). These dentin-derived proteins appear to regulate the migration and differentiation of DPSC (4) and appear to be required for the differentiation of odontoblasts $(21,24)$.

Morphogens, responsive cells, and scaffolds are critical components of tissue engineering. However, successful regenerative strategies require the rapid development of functional blood vessel networks (1). Despite its small size, de novo regeneration of pulp tissue is challenging because its anatomical characteristics are 
not particularly conducive to the rapid and effective vasculogenesis (1). Thus, the development of improved vasculogenesis strategies is an important challenge in the field of dental pulp tissue engineering. Vascular endothelial growth factor (VEGF) is the prototypic proangiogenic factor (33). It has been shown that VEGF enhances the neovascularization of severed human dental pulps $(34,35)$. In addition, DPSC are capable of differentiating into endothelial cells and give rise to functional blood vessels $(23,36)$. The use of scaffolds as a delivering system for VEGF has been explored as a mean to stimulate angiogenesis (37). Our laboratory is actively engaged in research to develop VEGF-containing scaffolds suitable for dental pulp tissue engineering.

Although the concept of engineering the entire tooth is exciting, there are many critical obstacles that may take several years to be overcome $(1,5,9)$. In contrast, the engineering of one dental tissue at a time might be a more realistic short-term goal. In this review, we will discuss key aspects of dental pulp tissue engineering focusing on the obstacles and opportunities of regenerative Endodontics.

\section{STEM CELLS OF DENTAL ORIGIN TO BE APPLIED IN REGENERATIVE STRATEGIES OF PULP TISSUE}

Isolation of human ESC (hESC) from the inner mass of human blastocyst (38) was a revolutionary episode in science, bringing exciting new perspectives in cell therapy. These cells are classified as pluripotent since they can differentiate in any body cell (11). However, $\mathrm{hESC}$ cannot be considered totipotent since they were not capable of producing all of the extra embryonic tissues required for mammalian development (39).

The isolation and use of hESC face ethical and legal barriers (12). Therefore, post-natal stem cells appear to be more indicated for tooth-related tissue engineering. Post-natal stem cells can be isolated from the individual who needs treatment, avoiding immunological reactions (39). Thus, post-natal stem cells (e.g. MSC) constitute an attractive source of cells for regenerative therapies $(9,40)$ because they have remarkable plasticity when exposed to foreign microenvironments (11).

MSC are clonogenic cells capable of both self-renewal and multilineage differentiation (9). The first MSC to be isolated and characterized were bone marrow MSC (BMMSC) (41). BMMSC cells have the potential to differentiate into osteoblasts, chondrocytes, adipocytes, and myelosupportive fibrous stroma (40). In the beginning of the 2000's, dental pulp stem cells (DPSC) were isolated from permanent teeth and characterized based on the gold standard criteria established for BMMSC (14). Dental-tissue derived MSC-like populations appear to be more committed to odontogenic rather than osteogenic development (40). In recent years, dental mesenchymal cells have been used in several studies to assess their potential in future clinical applications.

\section{STEM CELLS FROM THE PULP OF PERMANENT AND PRIMARY TEETH}

DPSC constitutes a heterogeneous cell population obtained from the pulp of permanent teeth by enzymatic digestion (14). DPSC cells are characterized by their ability to differentiate into multiple stromal cell lineages and to their clonogenic capacity (42). It has been demonstrated that DPSCs are able to adhere and proliferate in scaffolds (Fig. 1) and they can also differentiate into odontoblastic lineage cells (40). In vitro, DPSC demonstrate high frequency of colony formation, producing calcified nodules (14). Furthermore, DPSC seeded onto mechanically and chemically treated dentin surfaces differentiated towards odontoblast-like cells (43), showing that environmental cues influence DPSC plasticity (24). In vivo, transplantation into immune compromised mice demonstrated the ability of DPSC to generate tooth-like tissues expressing genes that are consistent with odontoblastic differentiation $(42,44)$. When seeded in scaffolds casted within the pulp chamber of tooth slices, DPSC were able to produce a pulp-like tissue (24). In contrast, when the same cells were implanted in a scaffold without dentin, they were unable to differentiate into odontoblasts.

Stem cells from human exfoliated deciduous teeth: SHED were isolated by Songtao Shi's group from the pulp of exfoliated primary teeth, using a similar strategy as that used for isolation of DPSCs (16). Similarly to DPSC, SHED demonstrated to be a population of highly proliferative, clonogenic cells, differentiating into a diversity of cell types including neural cells, adipocytes, and odontoblasts. SHED express STRO-1 and CD146, two MSC markers also present in DPSC, but SHED exhibited higher proliferation rates than DPSC (16). IDPS, another stem cell lineage from the pulp of primary teeth, express embryonic stem cell surface markers (15). In vivo, IDPS were capable of 
regenerating damaged corneal tissues in animal models (45). However, their potential to form pulp-like tissues in vivo has yet to be established.

Recent findings have strengthen the rationale for the use of SHED in dental pulp tissue engineering (21-24). When seeded in tooth/slice scaffolds together with HDMEC, SHED are able to form well-vascularized pulp-like tissues with morphology resembling that of a human dental pulp (22). Using similar approach (i.e. tooth slice/scaffold model), Casagrande et al. (21) showed that SHED differentiated into odontoblast-like cells, expressing three putative markers of odontoblastic differentiation (DSPP, DMP1, MEPE). The authors also demonstrated that blockade of bone morphogenetic protein 2 (BMP-2) signaling inhibited the differentiation of SHED into odontoblasts (21). These data began to unveil the nature of dentin-derived morphogenic signals required for SHED differentiation into odontoblasts (21). In parallel studies (23), SHED seeded in tooth slice/scaffolds differentiated into functional odontoblasts capable of generating new tubular dentin, as demonstrated by tetracycline staining. Additionally, SHED differentiate in functional endothelial cells (23). Furthermore, we have recently observed the formation of a well-organized pulp tissue inside the root canal of opened-apex maxillary first molars, using SHED with a self-assembled injectable scaffold. SHED differentiated into functional odontoblast capable of generating new dentin (46). These promising results suggest that primary teeth constitute a rich source of stem cells.

\section{STEM CELLS FROM THE APICAL PAPILLA}

SCAP were isolated from dental papilla (18), an embryonic-like tissue that originates the dental pulp during crown formation (12) and is located in tip of growing tooth roots (18). SCAP, similarly to DPSC and SHED, comprise a heterogeneous population capable of osteoblastic and odontoblastic differentiation, and to a lesser extend adipogenic differentiation (47). SCAP are also capable of expressing neurogenic (40) and myogenic markers $(19,47)$. Furthermore, SCAP show consistent capacity for dentin regeneration (18). Since the dental papilla is the precursor tissue for radicular pulp, it is possible that SCAP convert into DPSC, and therefore SCAP may constitute a population of earlier stem cells (40). Recent studies have shown that SCAP have the capacity to produce vascularized pulp-like tissue in vivo into 5-6 mm-long root canals (47). Furthermore, SCAP appear to undergo odontogenic differentiation as measured by expression of DSP, BSP, ALP, and CD105, indicating that the pulp-like tissue resembles human pulp tissue (47).

\section{PERIODONTAL LIGAMENT STEM CELLS}

Periodontal ligament (PDL) is a specialized connective tissue, which connects the radicular surface to the alveolar bone (48). The PDL has a heterogeneous cell population that can differentiate in either cementum or bone forming cells (5). Periodontal ligament stem cells (PDLSC) are capable of self-renewal and express the mesenchymal stem cell markers CD146/ MUC18, CD105, CD166, and STRO-1 (17). PDLSC cells also express tendon specific markers (40). These data suggests that PDLSC are a unique population of post-natal stem cells distinct from dental pulp or bone marrow-derived mesenchymal stem cell. Similar to
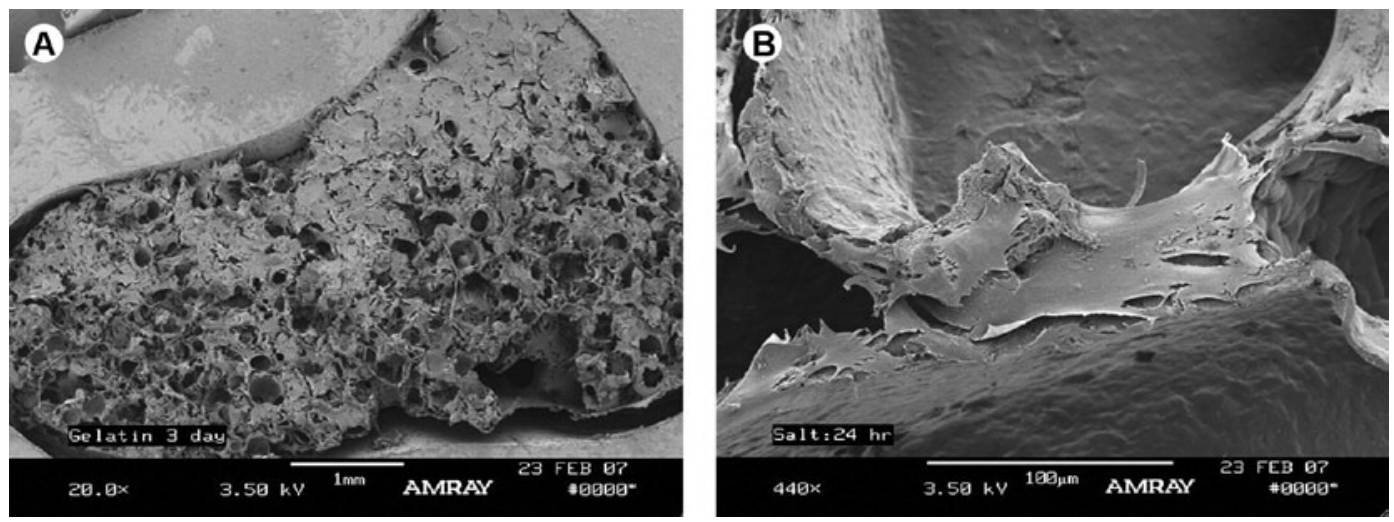

Figure 1. SEM micrographs. A = Lower magnification of DPSC cells growing in a tooth/slice scaffold. B = Higher magnification of DPSC cells attached to the porosity wall in a synthetic polymer (PLLA) scaffold. 
the stem cells of pulp origin, PDLSC are multipotent cells with potential for osteogenic, adipogenic and chondrogenic differentiation (40). When transplanted with HA/TCP into immunodeficient mice, PDLSC generated a cementum/PDL-like structure and contribute to periodontal tissue repair (17). Although there were no evidence for PDLSC forming pulp-like structures, when co-implanted with SCAP onto HA/TCP and gel-foam scaffolds in mini-pig models an engineered bio-root with functional PDL was formed (18).

\section{INDUCED PLURIPOTENT STEM CELLS}

Despite the fact that SHED can be obtained from exfoliated primary teeth and DPSC can be retrieved from third molars indicated for extraction, there are limitations to the use of these cells. For example, primary teeth are only available in children and frequently the amount of pulp tissue available is minimal. The method for generation of human iPS cells was first described in 2008 (49). Using different transcription factors (Oct4, Sox2, Klf4, Myc), adult human cells were reprogrammed to generate embryonic stem-like cells (49). iPS constitutes a new approach for the generation of stem cells for regenerative therapies, apparently devoid of issues related to immunocompatibility (50). However, there are significant risks involved with the use of iPS cells for tissue regeneration. Perhaps the most serious one is that some of the transcriptional factors used to reprogram the cells (e.g. c-Myc) are very well known oncogenes. Another issue is related to the fact that many times viruses are used to transfect these genes into the cells. It is well known that viruses that integrate into the host cell genome (e.g. retroviruses) have also intrinsic risks in regards to cell transformation. Nevertheless, if these issues are solved, iPS cells may constitute an attractive cellular source for tissue engineering.

\section{SCAFFOLDS FOR DENTAL PULP TISSUE ENGINEERING}

New strategies for dental pulp regeneration require the development of compatible biomaterials. As in any other tissue, the engineering of the dental pulp demands the association of appropriate cells with a conducive microenvironment (1). Scaffolds are three-dimensional structures that provide an initial framework for cells, and can be used to deliver morphogenic molecules $(51,52)$. After a scaffold has achieved these goals, they should degrade (26). The use of appropriate 3-D scaffolds allows cells to attach, grow and differentiate (27). The role of the scaffold becomes even more critical if one takes into account the challenges imposed by the quest for engineering a connective tissue within the confines of the human dental root. The necessity of recruiting blood vessels and neuronal structures solely through the apical foramina make the development of the scaffolds a critical step towards the goal of translating laboratory results into clinical use (53).

Scaffolds have been developed for research purposes (proof-of-principle), as well as for clinical use. Proof-of-principle scaffolds have provided critical information about mechanisms of dental pulp stem cell differentiation. On the other hand, scaffolds designed for potential clinical (Fig. 2) use will play a critical role in the translation of laboratory findings to the benefit of patients $(47,54,55)$.

The tooth slice/scaffold model using poly-1lactic acid (PLLA) has become a very useful model for mechanistic studies $(24,56)$. In this case, tooth slices obtained from freshly extracted human third molars have their pulp tissue removed and pulp chamber filled with a mixture of ground PLLA and sodium chloride. This mixture is then dissolved with chloroform and, after the complete evaporation of the solvent, the tooth slices/
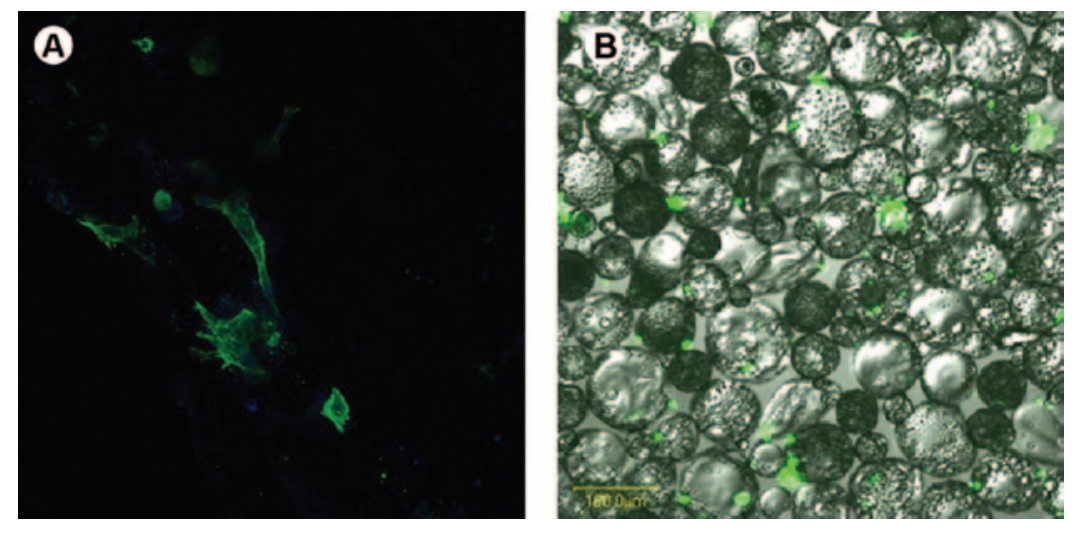

Figure 2. Two strategies to develop injectable scaffolds: using microspheres or selfassembly peptides. $A=$ Interaction of dental pulp stem cells (DPSC) in the RADA 16 self-assembly peptide, after $72 \mathrm{~h}$ of suspension. Courtesy of Dr. Benjamin Zeitlin. B $=$ Merged image of DPSC adhered to the micro spheres, as a strategy of producing an injectable scaffold to deliver the cells inside of the root canal. 
scaffolds are placed in water to dissolve the salt particles and creating the porosity required for cell seeding (24). After sterilization, these tooth slice/scaffolds can be implanted in immunodeficient mice. This approach allows for the genetic manipulation of the cells before transplantation, as well as it allows for the testing of the effect of different cell populations on dental pulp tissue engineering. Another approach involves the use of a co-polymer, i.e. poly-lactic-co-glycolic acid (PLGA), in the tooth slice/scaffold. In this case, one can control the degradation rate of the scaffold and incorporate morphogenic molecules using the scaffold as a slow release device. With this approach, one can study the effect of growth factors on cell metabolism and differentiation, as well as to study optimal conditions (e.g. concentration, timing of release) of these morphogenic factors (57). Slow-release scaffolds require a different approach for manufacturing that may involve gas-foaming techniques and/or the generation of microspheres containing the growth factors.

It has become clear that hard polymer scaffolds are likely not practical for clinical use. In this case, injectable scaffolds appear to be a better choice. Indeed, endodontists frequently inject medications into the root canal. Several scaffolds have already been proposed $(47,58)$. For example, self-assembly peptide hydrogels have several features that make them attractive for dental pulp tissue engineering purposes (54). They form a nanofiber mesh in a controllable manner, and they have relatively low cost. We have used Puramatrix (Bioscience, San Jose, CA, USA), a peptide matrix composed by multiple sequences of arginine (R), alanine (A), aspartate (D) and alanine (A). This scaffold has shown to promote cell growth and differentiation (59-61). In our initial experiments with this scaffold, it has shown compatibility with DPSC allowing them to grow and differentiate (Fig. 2). A recent study has demonstrated the promising possibility to produce a pulp-like tissue and functional odontoblast in several millimeters of the root canal, when using SHED with a injectable scaffold prepared with self-assembly peptide or collagen I (46).

The development of scaffolds is unquestionably a critical step towards the clinical application of dental pulp tissue engineering. The authors propose that the development of scaffolds for tooth regeneration constitutes a major opportunity for the future of dental biomaterials research. This is certainly an area that requires a multi-disciplinary approach involving the collaborative work of researchers with expertise in dental materials as well as investigators that have deep cell biology knowledge.

\section{MORPHOGENIC SIGNALING MOLECULES}

Morphogenetic signaling molecules are proteins that bind to specific cell membrane receptors and induce a cascade of processes that results in the generation of a new tissue $(1,30)$. Growth factors control the activity of stem cells, e.g. by regulating the rate of proliferation, inducing differentiation into another cell type, or by stimulating cells to synthesize mineralizable matrices $(62,63)$. Such molecules play a key role in the formation and repair of dentin and pulp. The formation of a mineralized barrier at sites of pulp exposure after direct pulp capping is an example of the potential of dental pulp repair (30). Notably, the dentin matrix is as a reservoir of growth factors capable of stimulating tissue response after being mobilized (4). Once released, these molecules play a key role in several signaling events such as the formation of tertiary dentin and repair (64).

Although the mechanisms underlying the reparative dentin formation have not been completely elucidated, it is known that proteins, such as BMP, have an important role (65-67). BMP are members of the transforming growth factor (TGF)-beta family. They were originally identified as regulators of cartilage and bone formation and they play an important role in embryogenesis and morphogenesis of various organs and tissues, including teeth (68). It has been demonstrated that human recombinant BMP (rhBMP-2, rhBMP-7) induce dentinogenesis $(65,66,69,70)$. The response of dental pulp cells to BMPs suggests that the cells present receptors for these bioactive molecules. BMP receptors (BMPR) are serine/threonine kinases that include type I receptors (BMPR-IA, BMPR-IB) and the type II receptor (BMPR-II). It was demonstrated that dental pulp cells (SHED, DPSC, fibroblasts) express BMPR-IA, BMPRIB and BMP-II receptors (21).

The growth factors BMP-2, BMP-4, BMP-6, BMP-7 and Gdf11 play an important role in the biology of pulp cells. Studies have shown that the expression of BMP-2 is increased during terminal differentiation of odontoblasts $(65,71)$, and that BMP-7 promotes the formation of reparative dentin mineralization in animal models (72). We have observed that dentin-derived BMP-2 is required for the differentiation of SHED into odontoblasts (21). The same signaling effect of dentin 
components on stem cells differentiation towards an odontoblast phenotype was observed for DPSCs (24). However, the ability to induce the formation of dentin is not limited to Gdf11 or BMPs. Recent research has shown that bone sialoprotein (BSP) stimulates the differentiation of pulp cells that secrete mineralizable matrices at the site of pulp exposure $(67,72)$. Notably, an excellent work from the Goldberg laboratory has demonstrated that the morphological characteristics of dentin are specifically correlated to the morphogenic factor used to induce it $(73,74)$.

BMP have been approved for treatment of bone fractures by the Food and Drug Administration in the United States. This has certainly provided a boost towards the application of bioactive molecules in regenerative endodontics. However, several questions remain unclear regarding to the use of morphogenic molecules in dental pulp tissue engineering. For example, it is well known that morphogenic factors have a tightly regulated temporal-spatial expression during embryogenesis (75). Such refined detail is still missing in the majority of the attempts explored so far for dental pulp tissue regeneration. The development of a strategy that allows for the controlled temporal-spatial delivery of growth factors appears to constitute an important area for future research and will likely involve work in the area of scaffold development.

\section{VASCULAR NETWORKS}

Successful tissue engineering relies on the establishment of an effective vascular network, able to supply the tissue with oxygen, nutrients and immune cells, while removing by-products and waste (33). The provision of nutrients and oxygen to the engineered constructs is critical for sustaining the high metabolic activity of cells that are engaged in tissue regeneration. Indeed, without the rapid establishment of a vascular network, either the volume of implanted tissues will be limited to 2 to $3 \mathrm{~mm}^{3}$ (76) or the cells will not survive the early post-transplantation stage. In fact, the diffusion of oxygen through tissues is typically limited to $100-200$ $\mu \mathrm{m}(9,24)$. Considering the anatomical characteristics of the root canal system, the development of strategies that enhance neovascularization is a major challenge in the field of dental pulp tissue engineering.

To overcome the problem of vascularization, strategies such as embedding angiogenic factors into the scaffold to promote ingrowth of microvessels, fabrication technologies to create polymers containing vessel-like networks, and prevascularization of matrices prior to cell seeding have been proposed $(77,78)$. Alternatively, one could exploit the inherent vasculogenic potential of endothelial cells (EC). Previous work showed that human microvascular endothelial cells transplanted in PLLA scaffolds differentiate into vascular structures that connect with the mouse vasculature via anastomosis and become functional human blood vessels containing host blood cells (79). Furthermore, these vessels undergo a process of maturation as determined by the gradual investment by host pericytes $(80)$.

However, in our initial attempts to co-transplant human endothelial cells and SHED into tooth slice/ scaffolds, we have not observed a significant increase in pulp microvessel density (22). In addition, the clinical use of mature endothelial cells is also limited by the typical low proliferative capacity of these cells (81). Such limitations have instigated the search for alternative strategies to induce tissue vascularization. Studying the rat acute myocardial infarction model, Gandia et al. (82) showed that DPSC induce angiogenesis, improve cardiac function, and reduce the infarct size. Another group reported that stromal stem cells from human dental pulp (SBP-DPSC) implanted subcutaneously into immunodeficient rats generated bone with its own blood supply, suggesting the stem cell differentiation into endotheliocytes (36). In models of mouse hind limb ischemia, the implantation of DPSC resulted in an increase in blood flow $(58,83)$.

Several growth factors and environmental conditions are able to affect vascular network formation. VEGF is the prototypic pro-angiogenic factor and studies have shown that VEGF induces stem cell differentiation into endothelial cells $(23,84)$. VEGF induced DPSC to acquire endothelial cell-like features when cultured in a 3-D fibrin mesh, displaying focal organization into capillary-like structures (85). When SHED were cultured in collagen matrices, they organized themselves into capillary structures that resemble microvessels. In addition, VEGF enhanced the differentiation of SHED into vascular endothelial cells (23).

When SHED were cultured in tooth slice/scaffolds and stimulated with VEGF, VEGFR2 expression was observed after the first day of stimulation. After 28 days, SHED also began to express PECAM-1 and VEcadherin, thus suggesting that SHED progressively acquired an endothelial phenotype when exposed to VEGF. In this case, VEGFR2 appeared at earlier stages 
of differentiation, while PECAM-1 and VE-cadherin in later maturation, confirming findings observed in other model systems (86).

The fate of SHED after transplantation into mice using the tooth slice/scaffold model was evaluated through the use of SHED stably transduced with LacZ. Beta-galactosidase-positive capillaries containing blood cells in the lumen were observed in the engineered dental pulps, confirming that the stem cells have differentiated into blood vessel-forming endothelial cells $(22,23)$. Possible sources of the angiogenic factors (e.g. VEGF) required for the differentiation of SHED into endothelial cells are the surrounding dentin (87) and host cells $(88,89)$. Notably, areas within tissue engineering constructs exhibit hypoxia, which is a very well described physiological condition in which angiogenesis is stimulated through the activation of transcriptional factors (e.g. HIF-1 alpha) and induction of VEGF expression (90).

Although significant progress towards the understanding of the angiogenic potential of DPSC has been made in recent years, much work remains to be done to optimize the conditions for rapid establishment of functional vascular networks in engineered dental pulps. We believe that this is a critical challenge that must be overcome before dental pulp tissue engineering approaches can be used in clinical Dentistry.

\section{CONCLUDING REMARKS}

The knowledge generated through basic science research in the fields of stem cell biology, biomaterials (scaffolds), and development (odontogenesis), coupled with recent advances in clinical research in the field of Endodontics, has come together at a time when tissue engineering-based therapies are being translated into clinical practice in Medicine. We are now at a stage in which engineering a complex tissue, such as the dental pulp, is no longer an unachievable dream. Rather, we see tissues that look and behave very much like a human dental pulp being engineered in laboratories throughout the world (Fig. 3). These outcomes provide evidence that suggests that it might be feasible to restore viability in a necrotic young permanent tooth by engineering a new dental pulp.

The potential impact of such therapies is immense. Dental pulp tissue engineering may allow for the completion and reinforcement of the tooth structure, potentially enhancing the long-term outcome of these necrotic teeth. However, the complete ramifications of such developments to Dentistry are far from being understood. For example, the multidisciplinary nature of the field of tissue engineering has stimulated researchers with different backgrounds to work together. We speculate that the personal interactions that are now being created by the search for the ideal combination of cells, scaffolds, and morphogenic factors for dental pulp tissue engineering may be extended over future years and
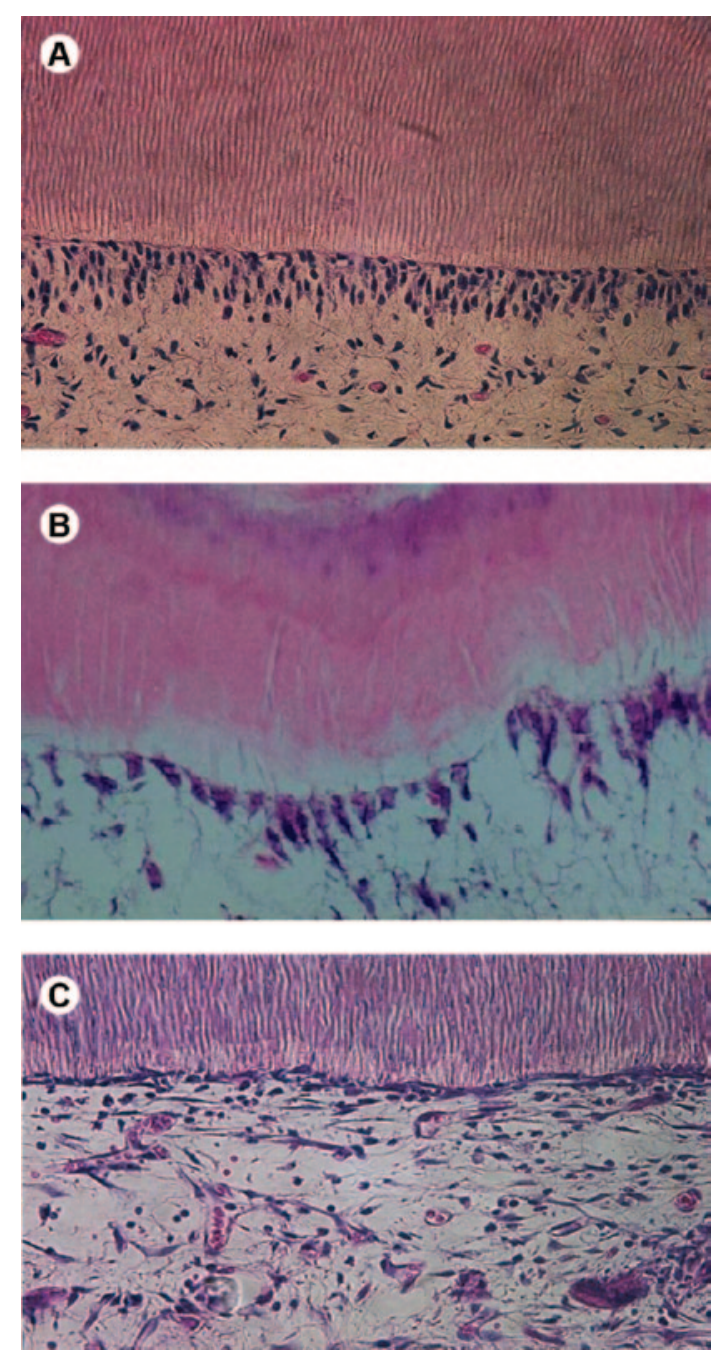

Figure 3. Histological analysis of pulp tissue. A = HE staining of a normal pulp showing the odontoblast layer aligned at the predentin interface $(400 \times$ magnification). $\mathrm{B}=$ Odontoblast-like cells aligned under the dentin barrier formed after 28 days of direct pulp capping with calcium hydroxide (400× magnification). $\mathrm{C}=$ Pulp-like tissue formed in a tooth/slice scaffold after 28 days of implantation in the back of SCID mice. Note that the histological features resemble more the tissue under the dentin barrier $(B)$ than the normal pulp (A), especially considering the lower number of odontoblast-like cells at the interface (400× magnification). 
result in significant advances in other areas of dental and craniofacial research. Importantly, those advances will likely be primarily focused on the biological regeneration of oral structures. The next decade will certainly be an exciting time for dental and craniofacial research.

\section{ACKNOWLEDGEMENTS}

The authors would like to thank the members of the Angiogenesis Research Laboratory at the University of Michigan Dental School for invaluable input and technical help during the execution of our pulp biology studies. We also would like to acknowledge the support received from Brazilian Government agencies CAPES and $\mathrm{CNPq}$ for the pursue of the studies discussed here that were performed by our research group.

\section{RESUMO}

A polpa dental é um tecido conjuntivo altamente especializado que possui uma restrita capacidade de regeneração, devido à sua disposição anatômica e à natureza pós-mitótica das células odontoblásticas. A remoção total da polpa, seguida da desinfecção do canal radicular e seu preenchimento com material artificial proporciona a perda de uma significante quantidade de dentina deixando como sequela um dente não vital e enfraquecido. Entretanto, a endodontia regenerativa é um campo emergente da engenharia tecidual, que demonstrou resultados promissores utilizando células-tronco associadas à scaffolds e moléculas bioativas. Desta forma, esse artigo revisa os recentes avanços obtidos na regeneração do tecido pulpar baseado nos princípios da engenharia tecidual e fornece aos leitores informações compreensivas sobre os diferentes aspectos envolvidos na engenharia tecidual. Assim, nós especulamos que a combinação ideal de células, scaffolds e moléculas bioativas pode resultar em significantes avanços em outras áreas da pesquisa odontológica. Os dados levantados em nossa revisão demonstraram que estamos em um estágio no qual, o desenvolvimento de tecidos complexos, tais como a polpa dental, não é mais inatingível e que a próxima década será um período extremamente interessante para a pesquisa odontológica.

\section{REFERENCES}

1. Nor JE. Tooth regeneration in operative dentistry. Oper Dent 2006;31:633-642.

2. Nakashima M, Akamine A. The application of tissue engineering to regeneration of pulp and dentin in endodontics. J Endod 2005;31:711-718.

3. Bjorndal L, Mjor IA. Pulp-dentin biology in restorative dentistry. Part 4: Dental caries-characteristics of lesions and pulpal reactions. Quintessence Int 2001;32:717-736.

4. Smith AJ, Lumley PJ, Tomson PL, Cooper PR. Dental regeneration and materials: a partnership. Clin Oral Investig 2008;12:103-108.

5. Huang GT. Pulp and dentin tissue engineering and regeneration: current progress. Regen Med 2009;4:697-707.

6. Arana-Chavez VE, Massa LF. Odontoblasts: the cells forming and maintaining dentine. Int J Biochem Cell Biol 2004;36:1367-1373.

7. Mjor IA. Dentin permeability: the basis for understanding pulp reactions and adhesive technology. Braz Dent J 2009;20:3-16.

8. Demarco FF, Rosa MS, Tarquinio SB, Piva E. Influence of the restoration quality on the success of pulpotomy treatment: a preliminary retrospective study. J Appl Oral Sci 2005;13:72-77.

9. Nedel F, Andre Dde A, de Oliveira IO, Cordeiro MM, Casagrande L, Tarquinio SB, et al.. Stem cells: therapeutic potential in dentistry. J Contemp Dent Pract 2009;10:90-96.

10. Langer R, Vacanti JP. Tissue engineering. Science 1993;260:920926.

11. Raff M. Adult stem cell plasticity: fact or artifact? Annu Rev Cell Dev Biol 2003;19:1-22.

12. Morsczeck C, Schmalz G, Reichert TE, Vollner F, Galler K, Driemel O. Somatic stem cells for regenerative dentistry. Clin Oral Investig 2008; 12:113-118.

13. Volponi AA, Pang Y, Sharpe PT. Stem cell-based biological tooth repair and regeneration. Trends Cell Biol 2010;20:715-722.

14. Gronthos S, Mankani M, Brahim J, Robey PG, Shi S. Postnatal human dental pulp stem cells (DPSCs) in vitro and in vivo. Proc Natl Acad Sci USA 2000;97:13625-13630.

15. Kerkis I, Kerkis A, Dozortsev D, Stukart-Parsons GC, Gomes Massironi SM, Pereira LV, et al.. Isolation and characterization of a population of immature dental pulp stem cells expressing OCT4 and other embryonic stem cell markers. Cells Tissues Organs 2006; 184:105-116.

16. Miura M, Gronthos S, Zhao M, Lu B, Fisher LW, Robey PG, et al.. SHED: stem cells from human exfoliated deciduous teeth. Proc Natl Acad Sci USA 2003

17. Seo BM, Miura M, Gronthos S, Bartold PM, Batouli S, Brahim J, et al.. Investigation of multipotent postnatal stem cells from human periodontal ligament. Lancet 2004;364:149-155.

18. Sonoyama W, Liu Y, Fang D, Yamaza T, Seo BM, Zhang C, et al.. Mesenchymal stem cell-mediated functional tooth regeneration in swine. PLoS One 2006;1:e79.

19. Sonoyama W, Liu Y, Yamaza T, Tuan RS, Wang S, Shi S, et al.. Characterization of the apical papilla and its residing stem cells from human immature permanent teeth: a pilot study. J Endod 2008;34:166-171.

20. Morsczeck C, Gotz W, Schierholz J, Zeilhofer F, Kuhn U, Mohl C, et al.. Isolation of precursor cells (PCs) from human dental follicle of wisdom teeth. Matrix Biol 2005;24:155-165.

21. Casagrande L, Demarco FF, Zhang Z, Araujo FB, Shi S, Nor JE. Dentin-derived BMP-2 and odontoblast differentiation. J Dent Res 2010;89:603-608.

22. Cordeiro MM, Dong Z, Kaneko T, Zhang Z, Miyazawa M, Shi S, et al.. Dental pulp tissue engineering with stem cells from exfoliated deciduous teeth. J Endod 2008;34:962-969.

23. Sakai VT, Zhang Z, Dong Z, Neiva KG, Machado MA, Shi S, et al.. SHED differentiate into functional odontoblasts and endothelium. J Dent Res 2010;89:791-796.

24. Demarco FF, Casagrande L, Zhang Z, Dong Z, Tarquinio SB, Zeitlin $\mathrm{BD}$, et al.. Effects of morphogen and scaffold porogen on the differentiation of dental pulp stem cells. J Endod 2010;36:1805-1811.

25. Park IH. Five classic articles in somatic cell reprogramming. The Yale Journal of Biology and Medicine 2010;83:135-137.

26. Barnes CP, Sell SA, Boland ED, Simpson DG, Bowlin GL. Nanofiber technology: designing the next generation of tissue engineering scaffolds. Adv Drug Deliv Rev 2007;59:1413-1433.

27. Yang S, Leong KF, Du Z, Chua CK. The design of scaffolds for use in tissue engineering. Part I. Traditional factors. Tissue Eng 2001;7:679-689.

28. Graziano A, d'Aquino R, Cusella-De Angelis MG, De Francesco F, Giordano A, Laino G, et al.. Scaffold's surface geometry significantly affects human stem cell bone tissue engineering. $\mathrm{J}$ 
Cell Physiol 2008;214:166-172.

29. Wei G, Jin Q, Giannobile WV, Ma PX. Nano-fibrous scaffold for controlled delivery of recombinant human PDGF-BB. J Control Release 2006;112:103-110.

30. Smith AJ. Vitality of the dentin-pulp complex in health and disease: growth factors as key mediators. J Dent Educ 2003;67:678-689.

31. Ruch JV, Lesot H, Begue-Kirn C. Odontoblast differentiation. Int J Dev Biol 1995;39:51-68.

32. Tomson PL, Grover LM, Lumley PJ, Sloan AJ, Smith AJ, Cooper PR. Dissolution of bio-active dentine matrix components by mineral trioxide aggregate. J Dent 2007;35:636-642.

33. Brey EM, Uriel S, Greisler HP, McIntire LV. Therapeutic neovascularization: contributions from bioengineering. Tissue Eng 2005; 11:567-584.

34. Goncalves SB, Dong Z, Bramante CM, Holland GR, Smith AJ, Nor JE. Tooth slice-based models for the study of human dental pulp angiogenesis. J Endod 2007;33:811-814.

35. Mullane EM, Dong Z, Sedgley CM, Hu JC, Botero TM, Holland GR, et al.. Effects of VEGF and FGF2 on the revascularization of severed human dental pulps. J Dent Res 2008;87:1144-1148.

36. d'Aquino R, Graziano A, Sampaolesi M, Laino G, Pirozzi G, De Rosa A, et al.. Human postnatal dental pulp cells co-differentiate into osteoblasts and endotheliocytes: a pivotal synergy leading to adult bone tissue formation. Cell Death Differ 2007;14:1162-1171.

37. Lokmic Z, Mitchell GM. Engineering the microcirculation. Tissue Eng Part B Rev 2008;14:87-103.

38. Thomson JA, Itskovitz-Eldor J, Shapiro SS, Waknitz MA, Swiergiel JJ, Marshall VS, et al.. Embryonic stem cell lines derived from human blastocysts. Science 1998;282:1145-1147.

39. Smith AG. Embryo-derived stem cells: of mice and men. Annu Rev Cell Dev Biol 2001;17:435-462.

40. Huang GT, Gronthos S, Shi S. Mesenchymal stem cells derived from dental tissues $v s$. those from other sources: their biology and role in regenerative medicine. J Dent Res 2009;88:792-806.

41. Prockop DJ. Marrow stromal cells as stem cells for nonhematopoietic tissues. Science 1997;276:71-74.

42. Gronthos S, Brahim J, Li W, Fisher LW, Cherman N, Boyde A, et al.. Stem cell properties of human dental pulp stem cells. J Dent Res 2002;81:531-535.

43. Huang GT, Shagramanova K, Chan SW. Formation of odontoblastlike cells from cultured human dental pulp cells on dentin in vitro. J Endod 2006;32:1066-1073.

44. Batouli S, Miura M, Brahim J, Tsutsui TW, Fisher LW, Gronthos $\mathrm{S}$, et al.. Comparison of stem-cell-mediated osteogenesis and dentinogenesis. J Dent Res 2003;82:976-981.

45. Gomes JA, Geraldes Monteiro B, Melo GB, Smith RL, Cavenaghi Pereira da Silva M, Lizier NF, et al.. Corneal reconstruction with tissue-engineered cell sheets composed of human immature dental pulp stem cells. Invest Ophthalmol Vis Sci 2010;51:1408-1414.

46. Rosa V. Stem cells from exfoliated deciduous teeth and selfassembling nanofiber and recombinant human collagen I scaffolds allows for the engineering of a functional dental pulp. [Doctoral Thesis]. São Paulo: Faculdade de Odontologia da Universidade de São Paulo, Universidade de São Paulo; 2010. 98p.

47. Huang GT, Yamaza T, Shea LD, Djouad F, Kuhn NZ, Tuan RS, et al.. Stem/progenitor cell-mediated de novo regeneration of dental pulp with newly deposited continuous layer of dentin in an in vivo model. Tissue Eng Part A 2010;16:605-615.

48. Villar CC, Cochran DL. Regeneration of periodontal tissues: guided tissue regeneration. Dent Clin North Am 2010;54:73-92.

49. Park IH, Arora N, Huo H, Maherali N, Ahfeldt T, Shimamura A, et al.. Disease-specific induced pluripotent stem cells. Cell 2008; $134: 877-886$

50. Tamaoki N, Takahashi K, Tanaka T, Ichisaka T, Aoki H, Takeda-
Kawaguchi T, et al.. Dental pulp cells for induced pluripotent stem cell banking. J Dent Res 2010;89:773-778.

51. Murphy WL, Mooney DJ. Controlled delivery of inductive proteins, plasmid DNA and cells from tissue engineering matrices. J Periodontal Res 1999;34:413-419.

52. Muschler GF, Nakamoto C, Griffith LG. Engineering principles of clinical cell-based tissue engineering. J Bone Joint Surg Am 2004;86-A:1541-1558.

53. Hargreaves KM, Giesler T, Henry M, Wang Y. Regeneration potential of the young permanent tooth: what does the future hold? J Endod 2008;34:S51-56.

54. Galler KM, Cavender A, Yuwono V, Dong H, Shi S, Schmalz G, et al.. Self-assembling peptide amphiphile nanofibers as a scaffold for dental stem cells. Tissue Eng Part A 2008;14:2051-2058.

55. Zhang W, Walboomers XF, van Kuppevelt TH, Daamen WF, Bian Z, Jansen JA. The performance of human dental pulp stem cells on different three-dimensional scaffold materials. Biomaterials 2006;27:5658-5668.

56. Wang J, Liu X, Jin X, Ma H, Hu J, Ni L, et al.. The odontogenic differentiation of human dental pulp stem cells on nanofibrous poly(l-lactic acid) scaffolds in vitro and in vivo. Acta Biomater 2010;6:3856-3863.

57. Murphy WL, Peters MC, Kohn DH, Mooney DJ. Sustained release of vascular endothelial growth factor from mineralized poly(lactide-co-glycolide) scaffolds for tissue engineering. Biomaterials 2000;21:2521-2527.

58. Iohara $\mathrm{K}$, Zheng $\mathrm{L}$, Ito $\mathrm{M}$, Ishizaka $\mathrm{R}$, Nakamura $\mathrm{H}$, Into $\mathrm{T}$, et al.. Regeneration of dental pulp after pulpotomy by transplantation of CD31(-)/CD146(-) side population cells from a canine tooth. Regen Med 2009;4:377-385.

59. Misawa H, Kobayashi N, Soto-Gutierrez A, Chen Y, Yoshida A, Rivas-Carrillo JD, et al.. PuraMatrix facilitates bone regeneration in bone defects of calvaria in mice. Cell Transplant 2006;15:903910.

60. Narmoneva DA, Oni O, Sieminski AL, Zhang S, Gertler JP, Kamm $\mathrm{RD}$, et al.. Self-assembling short oligopeptides and the promotion of angiogenesis. Biomaterials 2005;26:4837-4846.

61. Thonhoff JR, Lou DI, Jordan PM, Zhao X, Wu P. Compatibility of human fetal neural stem cells with hydrogel biomaterials in vitro. Brain Res 2008;1187:42-51.

62. Martin I, Padera RF, Vunjak-Novakovic G, Freed LE. In vitro differentiation of chick embryo bone marrow stromal cells into cartilaginous and bone-like tissues. J Orthop Res 1998;16:181189.

63. Stevens MM, Marini RP, Schaefer D, Aronson J, Langer R, Shastri VP. In vivo engineering of organs: the bone bioreactor. Proc Natl Acad Sci USA 2005;102:11450-11455.

64. Tziafas D. Basic mechanisms of cytodifferentiation and dentinogenesis during dental pulp repair. Int J Dev Biol 1995;39:281-290.

65. Nakashima M. Induction of dentine in amputated pulp of dogs by recombinant human bone morphogenetic proteins- 2 and -4 with collagen matrix. Arch Oral Biol 1994;39:1085-1089.

66. Rutherford RB, Wahle J, Tucker M, Rueger D, Charette M. Induction of reparative dentine formation in monkeys by recombinant human osteogenic protein-1. Arch Oral Biol 1993;38:571-576.

67. Six N, Lasfargues JJ, Goldberg M. Differential repair responses in the coronal and radicular areas of the exposed rat molar pulp induced by recombinant human bone morphogenetic protein 7 (osteogenic protein 1). Arch Oral Biol 2002;47:177-187.

68. Thesleff I, Sharpe P. Signalling networks regulating dental development. Mech Dev 1997;67:111-123.

69. Jepsen S, Albers HK, Fleiner B, Tucker M, Rueger D. Recombinant 
human osteogenic protein-1 induces dentin formation: an experimental study in miniature swine. J Endod 1997;23:378-382.

70. Six N, Decup F, Lasfargues JJ, Salih E, Goldberg M. Osteogenic proteins (bone sialoprotein and bone morphogenetic protein-7) and dental pulp mineralization. J Mater Sci Mater Med 2002;13:225232.

71. Nakashima M, Reddi AH. The application of bone morphogenetic proteins to dental tissue engineering. Nat Biotechnol 2003;21:10251032.

72. Decup F, Six N, Palmier B, Buch D, Lasfargues JJ, Salih E, et al. Bone sialoprotein-induced reparative dentinogenesis in the pulp of rat's molar. Clin Oral Investig 2000;4:110-119.

73. Goldberg M, Lacerda-Pinheiro S, Jegat N, Six N, Septier D, Priam F, et al.. The impact of bioactive molecules to stimulate tooth repair and regeneration as part of restorative dentistry. Dent Clin North Am 2006;50:277-298.

74. Goldberg M, Six N, Decup F, Lasfargues JJ, Salih E, Tompkins $\mathrm{K}$, et al.. Bioactive molecules and the future of pulp therapy. Am J Dent 2003;16:66-76.

75. Goldberg M, Smith AJ. Cells and extracellular matrices of dentin and pulp: a biological basis for repair and tissue engineering. Crit Rev Oral Biol Med 2004;15:13-27.

76. Shieh SJ, Vacanti JP. State-of-the-art tissue engineering: from tissue engineering to organ building. Surgery 2005;137:1-7.

77. Chrobak KM, Potter DR, Tien J. Formation of perfused, functional microvascular tubes in vitro. Microvasc Res 2006;71:185-196.

78. Peters MC, Polverini PJ, Mooney DJ. Engineering vascular networks in porous polymer matrices. J Biomed Mater Res 2002;60:668-678.

79. Nor JE, Christensen J, Mooney DJ, Polverini PJ. Vascular endothelial growth factor (VEGF)-mediated angiogenesis is associated with enhanced endothelial cell survival and induction of Bcl-2 expression. Am J Pathol 1999;154:375-384.

80. Nor JE, Peters MC, Christensen JB, Sutorik MM, Linn S, Khan MK, et al.. Engineering and characterization of functional human microvessels in immunodeficient mice. Lab Invest 2001;81:453463.
81. Melero-Martin JM, Khan ZA, Picard A, Wu X, Paruchuri S, Bischoff J. In vivo vasculogenic potential of human blood-derived endothelial progenitor cells. Blood 2007;109:4761-4768.

82. Gandia C, Arminan A, Garcia-Verdugo JM, Lledo E, Ruiz A, Minana MD, et al.. Human dental pulp stem cells improve left ventricular function, induce angiogenesis, and reduce infarct size in rats with acute myocardial infarction. Stem Cells 2008;26:638645.

83. Nakashima M, Iohara K, Sugiyama M. Human dental pulp stem cells with highly angiogenic and neurogenic potential for possible use in pulp regeneration. Cytokine Growth Factor Rev 2009;20:435-440.

84. Jazayeri M, Allameh A, Soleimani M, Jazayeri SH, Piryaei A, Kazemnejad S. Molecular and ultrastructural characterization of endothelial cells differentiated from human bone marrow mesenchymal stem cells. Cell Biol Int 2008;32:1183-1192.

85. Marchionni C, Bonsi L, Alviano F, Lanzoni G, Di Tullio A, Costa $\mathrm{R}$, et al.. Angiogenic potential of human dental pulp stromal (stem) cells. Int J Immunopathol Pharmacol 2009;22:699-706.

86. Kim GD, Kim GJ, Seok JH, Chung HM, Chee KM, Rhee GS. Differentiation of endothelial cells derived from mouse embryoid bodies: a possible in vitro vasculogenesis model. Toxicol Lett 2008;180:166-173.

87. Roberts-Clark DJ, Smith AJ. Angiogenic growth factors in human dentine matrix. Arch Oral Biol 2000;45:1013-1016.

88. Tran-Hung L, Laurent P, Camps J, About I. Quantification of angiogenic growth factors released by human dental cells after injury. Arch Oral Biol 2008;53:9-13.

89. Tran-Hung L, Mathieu S, About I. Role of human pulp fibroblasts in angiogenesis. J Dent Res 2006;85:819-823.

90. Maxwell PH, Ratcliffe PJ. Oxygen sensors and angiogenesis. Semin Cell Dev Biol 2002;13:29-37. ; 100:5807-5812.

Accepted November 20, 2010 